\title{
Glaze production at an Early Islamic workshop in al-Andalus
}

\author{
Elena Salinas ${ }^{1}$, Trinitat Pradell ${ }^{1} J_{u d i t}$ Molera $^{2}$ \\ ${ }^{1}$ Physics Department and Barcelona Research Centre in Multiscale Science and Engineering, Universitat \\ Politècnica de Catalunya, Campus Diagonal Besòs, Av. Eduard Maristany, 10-14 08019 Barcelona, Spain \\ ${ }^{2}$ GR-MECAMAT, Universitat de Vic-Universitat Central de Catalunya (UVIC-UCC), Campus Torre dels Frares, \\ C/ de la Laura 13, 08500, Vic, Spain
}

\begin{abstract}
The study and analysis of the materials found in one of the earliest Islamic glazed ceramics workshop in al-Andalus (Pechina) dating from the second half of the $9^{\text {th }}$ century, including fritting vessels, kiln furniture, wasters and slags, and a glass chunk, has revealed the materials used and methods of production.

Galena was oxidised to obtain PbO in the workshop. Fritting of the glaze involved a two-stage process for which two different types of vessels were used. The fritting process ended with a melt which was poured to obtain a high lead glass. The ground glass was applied over the biscuit fired ceramics, and fired to a temperature high enough to soften the glaze and adhere it onto the ceramic surface. Evidences-of a similar process was found in a later workshop in San Nicolas ( $10^{\text {th }}$ century) which demonstrates the persistence of the technique in al-Andalus during the caliphal period.

There is little evidence of early Islamic glaze manufacture at kiln sites and in contrast to the glass workshops the glazed ceramics workshops have not been studied. Consequently, this study adds valuable information to the currently very limited knowledge about the early glaze technology in Dar al-Islam.
\end{abstract}




\section{INTRODUCTION}

Al-Andalus was from 711 to $1492 \mathrm{AD}$ the western end of the Islamic world. There is no evidence of glazed wares production in the Iberian Peninsula during the first 150 years of the Islamic presence, even though new unglazed pottery types were introduced from the Eastern regions. This contrasts with the early production of glazed pottery in other Islamic regions, such as Raqqa, Fustat, Basra, etc. Nevertheless, the production of glazed wares reached al-Andalus in the mid-ninth century, within the context of the technological revolution related to the production of glazed ceramics spreading through the Islamic lands, even beyond the boundaries of the Abbasid world.

Pechina -southeast of al-Andalus- was the first place known so far to produce transparent glazed ceramics; mainly plain green and amber glazes which were applied over pitchers, jugs, serving dishes and oil lamps. Neither polychrome combinations nor painted compositions were used in this workshop. In the 1980s, a craft area built in the $9^{\text {th }}$ century, which included workshop structures, kilns, a debris site containing glazed ceramics and wasters, slags, workshop furniture (tripods and kiln rods) and fritting vessels, was discovered and excavated. This craft area had a short lifetime and was destroyed with the construction of a residential area in the late $9^{\text {th }}$ century or beginning of the $10^{\text {th }}$ century, thus giving a precise dating to the workshop.

The study and analysis of the materials found in the workshop, in particular the fritting vessels, wasters and slags has revealed the materials used and methods of production. The results have given direct information about how this glazed pottery was manufactured.

There is little previous evidence of early Islamic glaze manufacture at kiln sites. Some glazed ceramic workshops were documented in Raqqa (c. AD 796-809) (François, Shaddoud 2013; Watson 1999) and a few kilns were excavated in Basra (Hallett 1990). However, no contemporary glazed ceramic kilns were found at other Mesopotamian settlements, neither Egypt nor Ifriqiyya (Gayraud, Vallaury 2017; Gragueb 2017). In contrast to the glass workshops (Freestone et al. 2015), glazed ware workshops have not been studied. Consequently, this study adds valuable information to the currently very limited knowledge about the early glaze technology in Dar al-Islam.

\subsection{History of Pechina}

Bajjana, or Pechina as it is known among the research community, was essentially a farming town settled in the fertile Valley of Andarax and with an agricultural based economy. The territory of Pechina was known as Urš al-Yaman (land allocated to the Arabs of Yemen), because the Amir 'Abd al-Rahmmān II (AD 840) assigned the coastline defence to the Banu Sarray Yemeni family. Very soon its inhabitants started to produce silk and linen fabrics which were traded across the Mediterranean, to Egypt, Mecca and Yemen expanding the economy and attracting a new population. During the second half of the $9^{\text {th }}$ century, when the town reached its maximum splendour, a group of sailors coming from Ténes (N. Africa) settled in Bajjana and declared the Independent Maritime Republic of Pechina (AD 884-885) separate from the al-Andalus Umayyad power, in exchange for paying taxes to the Umayyad Amir Muhammad I. During this period, and according to the historians, the city had extended over circa 40-50 hectares and a population increasing to 20000 people. This political situation lasted until AD 922 when the Amir 'Abd alRaḥmān III incorporated the territory again into the al-Andalus Umayyad power. Then, after AD 955, the Caliph reinforced the position of al-Mariyya (current Almería), located a few kilometres away, at the expense of Pechina. The population moved to the new location and Pechina was abandoned (Cara 2011; Castillo et al 1987).

From ancient times, iron, copper, silver and lead were exploited in the Pechina area. This mineral wealth facilitated the access to the raw materials necessary for producing the glazes. This proximity 
was crucial because of the al-Andalusian political instability and civil war existing (AD 878-928) previous to the proclamation of the Caliphate of Cordoba by 'Abd al-Raḥmān III (AD 929).

\subsection{The Pechina pottery workshop}

A craft area was built in the $9^{\text {th }}$ century on the Pechina outskirts. A pottery kiln; a second smaller kiln, identified by the archaeologists as a glass furnace; and a dump belonging to the workshop activity, containing glazed ceramics and wasters, workshop furniture (tripods and kiln rods), fritting vessels, slags and a crucible, were found (Figure 1). This area had a short lifetime being destroyed by the construction of a residential area a few years later (late $9^{\text {th }}-10^{\text {th }}$ centuries).
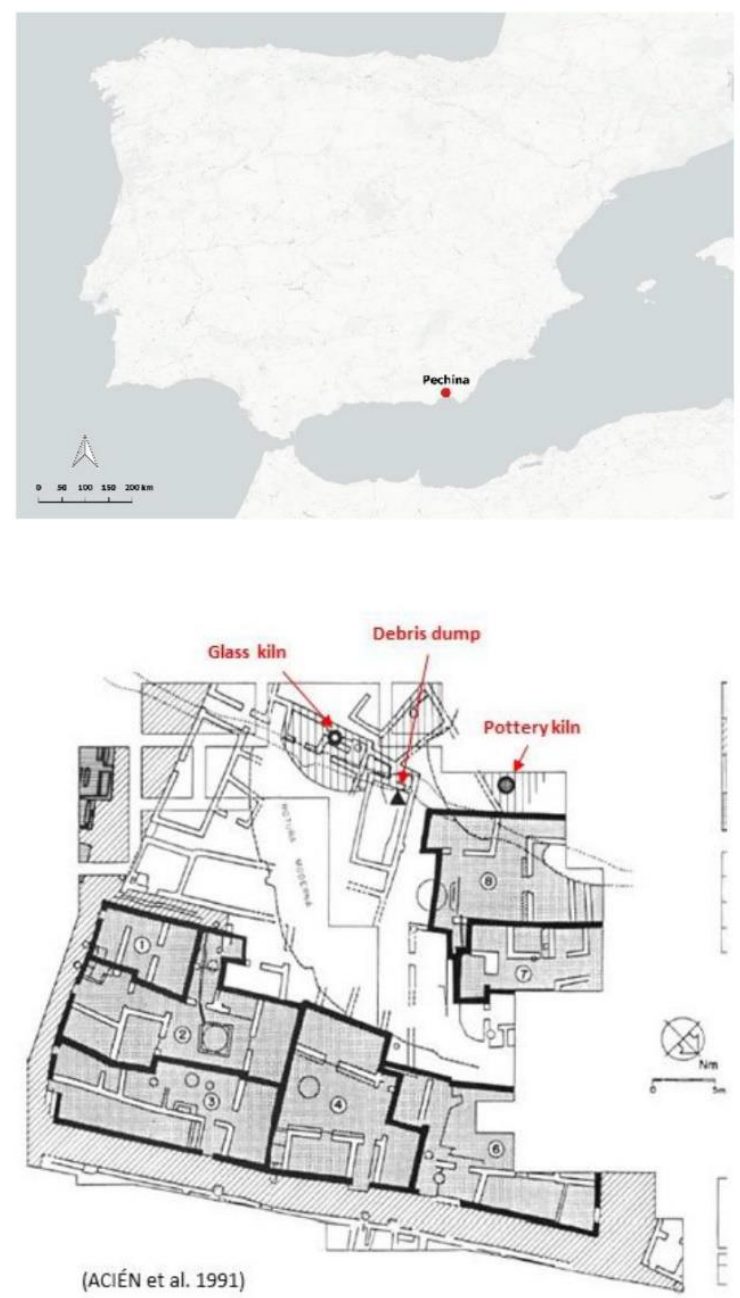

Figure 1. a) Map showing locations of sites mentioned in the text. b) Plan of Pechina workshop archaeological site, showing kilns and debris dump (from Acién et al. 1990).

Below is a summary of the elements related to the workshop activity:

- Two kilns: the first kiln, which was partially destroyed, had a circular shape and was related to the pottery production; part of its grill was found in the associated debris. The second kiln, which was initially associated with glass production by the archaeologists, had a rectangular shape and a small circular fire chamber $(60 \mathrm{~cm}$ diameter).

- Kiln furniture: finger shaped rods, one straight with a pointed end and the other curved (Figure 2D), and tripods with pointed ends were found (Figure 2A) and were employed in a grill kiln. Kiln 
rods were used in al-Andalus prior to the arrival of tin-glazed technology and prior to the use of bar kilns, which are not found in al-Andalus before the $10^{\text {th }}$ century (Coll, García, 2010). In a workshop from Malaga $\left(9^{\text {th }}-10^{\text {th }}\right.$ centuries), finger shaped rods were used in vertical position, nailed on the grill surface, to hold the pile of glazed dishes and to avoid the ceramics falling during the firing (personal communication from Sonia López Chamizo, Arqueosur-Estudio de Arqueologia S.L.). Moreover, in a contemporary Cordoba workshop area, where more than one hundred grill kilns were found, some of them associated to lead glazed production (Larrea, 2012).

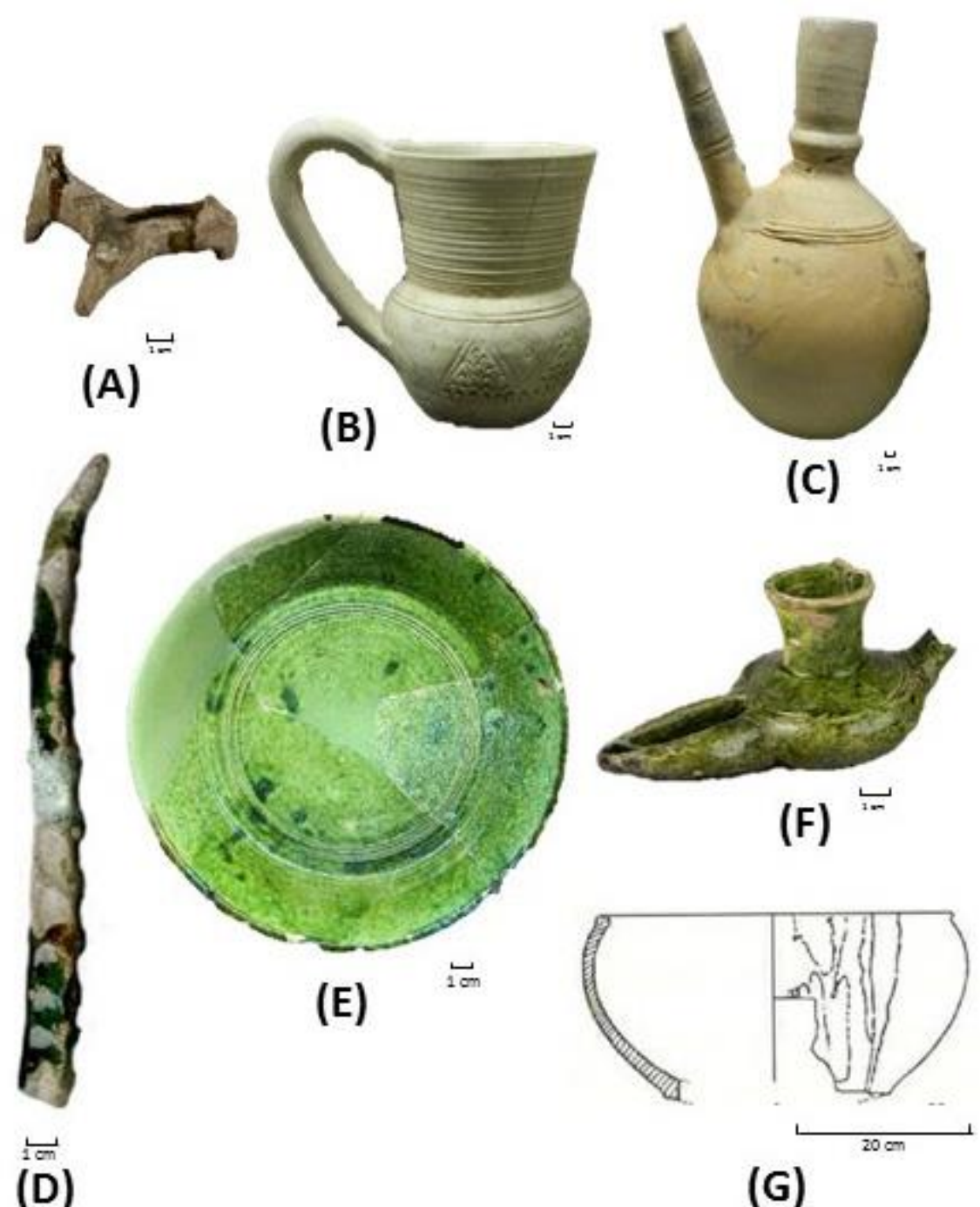

Figure 2. Representative material from Pechina workshop: (A) tripod stand, (B) pitcher, (C) jug, (D) kiln rod, (E) serving dish, (F) oil lamp.

- Fritting vessels: two different types of vessels, which were initially regarded as cooking pots but which were in fact associated with the glaze production, were found (Figure 3). Type I fritting vessels are hand-made, have straight walls, flat wing-like horizontal handles and a flat bottom whereas Type II are wheel-thrown and have a globular shape and large open vertical handles. They show a white clayish layer, covered by a rough glaze, coating the inner surface and drips over the outer surface. 


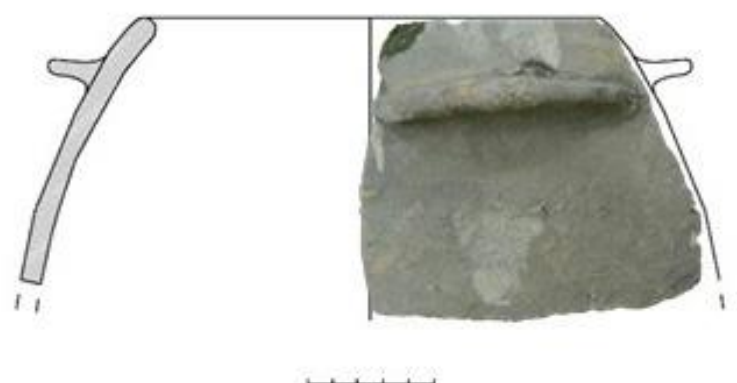

(A)

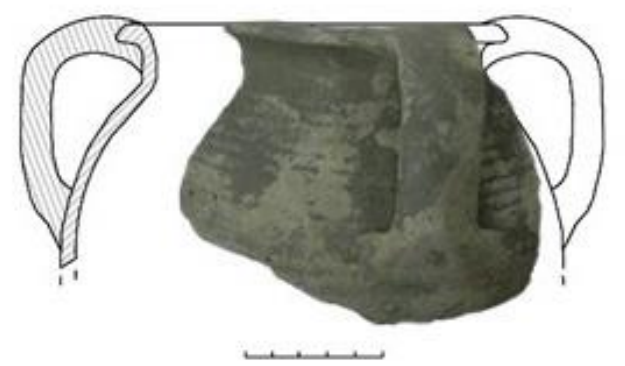

(C)

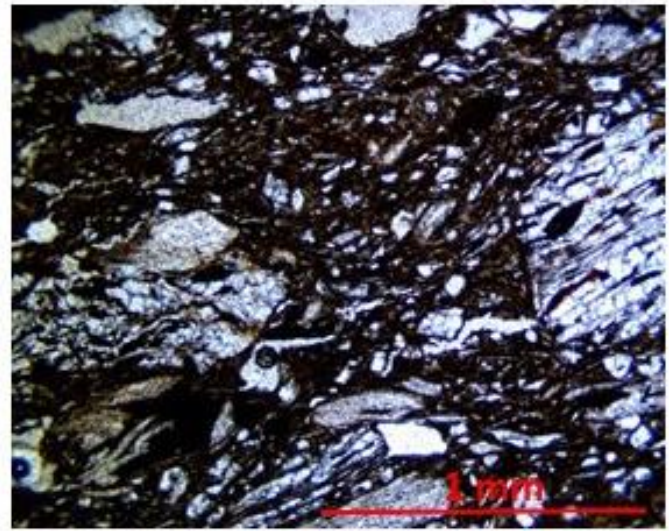

(B)

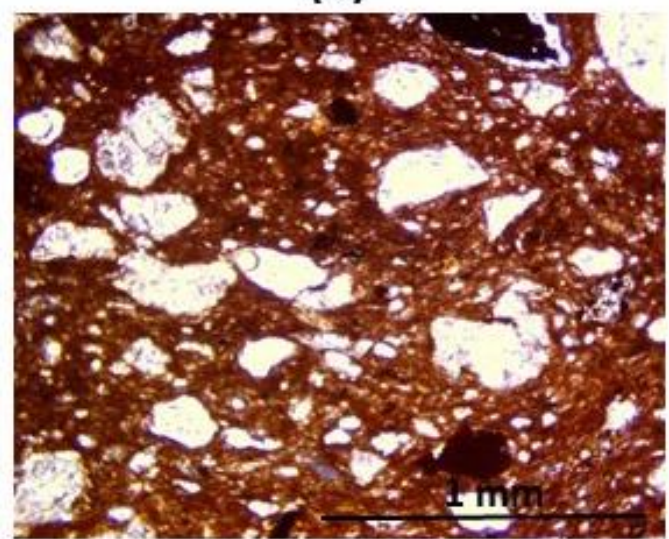

(D)

Figure 3. (A) Fritting vessel type I and (B) fabric of vessel type I (PE158), (C) fritting vessel type II and (D) fabric of vessel type II (PE 17).

- Slags: two big pieces, one with a convex curved surface and the other with a flat surface (Figure 4A and $B$ respectively), and many shapeless fragments. In addition, there was a flat brown glass chunk (Figure 4C). These were mostly concentrated in a room next to the kilns.

- Basins: glazed inside with glaze drips outside and showing a pair of symmetrical small holes drilled near the edge. They could have been used for the immersion of the ceramic objects in the glaze slurry.

- Glazed ware debris: a large amount of ceramic wasters mainly of tableware, consisting of different types of drinking pitchers (Figure 2B), jugs (Figure 2C), flat serving dishes (Figure 2E) and oil lamps (Figure 2F), were found in the dump area. Among these wasters, we could see glazed and unglazed sherds of the same types of pitchers and serving dishes, which provides a direct indication of a double firing process, the glaze being applied over the biscuit fired objects. The absence of other ceramic products indicates that the workshop specialised in glazed wares.

- According to the archaeologists a possible crucible (Figure 2G) with the size matching that of the second kiln and thought to be associated with glass production was recovered. However, we did not have access to this piece. 
(A)
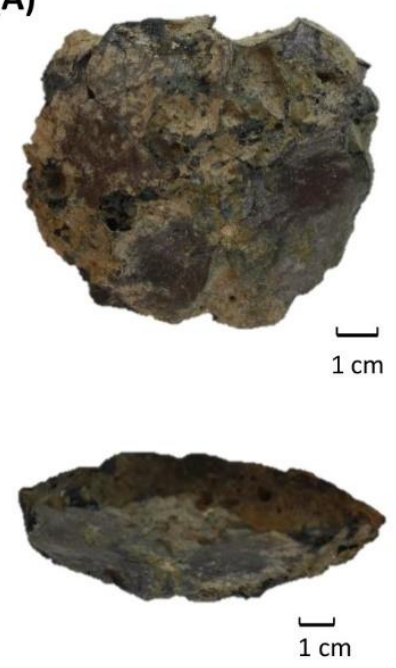

(B)
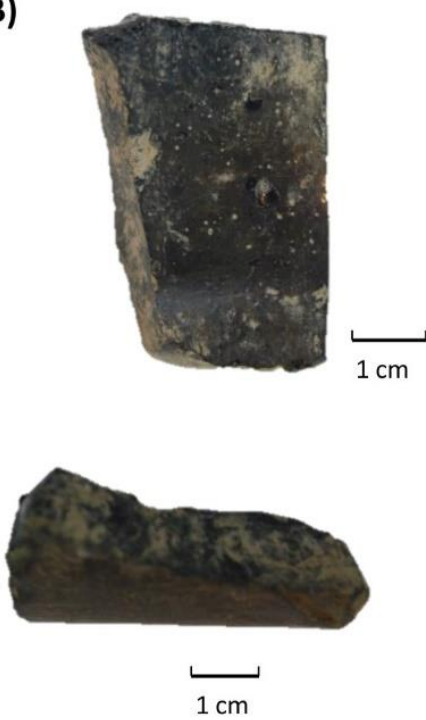

(c)
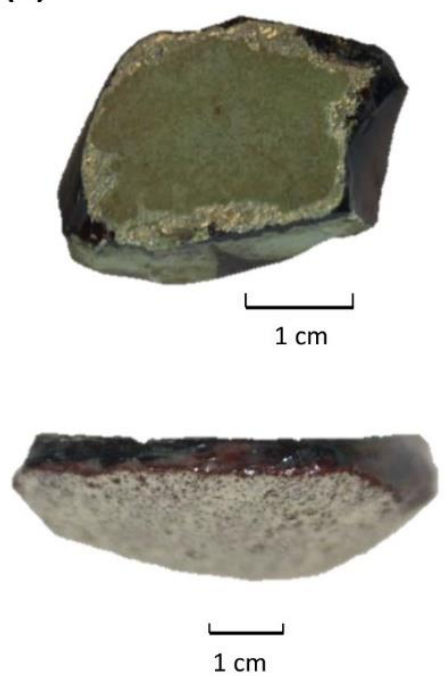

Figure 4. Glaze slags. (A) a convex surface (PE385) (B) a flat surface (PE340) and (C) glass chunk (PE300) showing an iridescent surface and a clayish surface.

\section{MATERIALS AND METHODS}

\subsection{Samples}

A total of seventeen sherds and seven slags/glass samples were selected: seven fritting vessels, two of Type I (PE12 and PE158) and five of Type II (PE17, PE21, PE61, PE166 and PE97); seven glazed ceramics, three pitchers (PE62, PE92 and PE46) illustrating the two most common types, four serving dishes (PE14, PE66, PE7 and PE162) representing the two different shapes, and one oil lamp (PE44); two elements of kiln furniture, one rod (PE55) and one tripod (PE3); four shapeless slag fragments (PE381, PE382, PE383, SL384), one slag piece with a curved surface (PE385) and one with a flat surface (PE340), and a glass chunk (PE300).

In the context of glaze colours, the limited colour range used in this workshop is remarkable. The pieces are plain monochrome or bichrome (each surface of a different colour) and the colours used are green, greenish or amber with different combinations: the serving dishes are brown outside and green inside, some pitchers are unglazed outside and greenish inside, other pitchers are green outside and brown inside and the oil lamps are monochrome green.

\subsection{Analytical techniques}

Polished cross sections of the sherds were prepared and coated with a sputtered carbon layer $(<20$ $\mu \mathrm{m}$ thick). The polished sections were examined at the Universitat Politècnica de Catalunya (Barcelona) both in reflected light with an optical microscope (OM), and in a crossbeam workstation (Zeiss Neon 40) equipped with scanning electron microscopy (SEM) GEMINI (Shottky FE) column with attached EDS (INCAPentaFETx3 detector, 30 $\mathrm{mm}^{2}$, ATW2 window, resolution $123 \mathrm{eV}$ at the Mn $\mathrm{K} \alpha$ energy line), operated at $20 \mathrm{kV}$ acceleration voltage with $1.1 \mathrm{~nm}$ lateral resolution, $20 \mathrm{nA}$ current, $7 \mathrm{~mm}$ working distance and 120s measuring times. The glaze and body microstructures were studied and recorded in Back-scattered Electron mode (BSE) in which the different phases present could be distinguished on the basis of their atomic number contrast. BSE images of the microstructures were obtained at $20 \mathrm{kV}$ acceleration voltage. 
The chemical compositions of the bodies were determined by analysing a minimum of two areas, each of a few square millimetres. The analyses of the ceramic bodies, which typically totalled $60 \%$ because of the porosity, were normalised to $100 \mathrm{wt} \%$ and then averaged. For the glazes, the areas analysed were chosen to avoid areas of weathered glaze and areas near to the glaze-body interface although on some cases, due to the poor conservation of the glazes, this was not possible. The results were again normalised, typical totals varying between 96 and 102\%, mainly due to the poor conservation of the glazes, and were then averaged. The EDS elemental microanalysis system was calibrated with oxide, mineral and a high lead - K229- glass standards (Geller Microanalytical Laboratory, MA, USA). Typical detection limits are $0.1 \%$ for $\mathrm{Na}, \mathrm{Mg}, \mathrm{Al}, \mathrm{P}, \mathrm{K}, \mathrm{Ca}, \mathrm{Ti}$ and $\mathrm{Fe}, 0.2$ for $\mathrm{Si}$ and $\mathrm{Cu}, 0.3$ for $\mathrm{Sn}$ and 0.4 for $\mathrm{Pb}$.

$\mu$-XRD data were obtained at the Materials Science and Powder Diffraction beamline (MCPDS BL04) in the Synchrotron Light Facility Alba-Cells (Cerdanyola, Spain) using polished thin cross sections (about $200 \mu \mathrm{m}$ thick) of the glazes in transmission geometry, using $0.4243 \AA$ wavelength ( $30 \mathrm{keV}$ ), a $20 \times 20 \mu \mathrm{m}^{2}$ spot size, and a CCD camera, SX165 (Rayonix, L.L.C., Evanston, IL) detector.

\section{RESULTS}

The chemical analyses of the bodies of the kiln furniture, fritting vessels and glazed wares are given in Table I. The analysis of the glazes associated with the kiln furniture, fritting vessels and glazed wares are shown in Table II while those corresponding to the protecting and glaze layers inside the fritting vessels are shown in Table III. Finally, the chemical analysis from the slags is shown in Table IV and from the glass chunk in Table V.

\subsection{Glazed wares}

Pechina wares have calcareous bodies (between 15\% and 20\% CaO) (Table I) and show a fine fabric containing small fragments of metamorphic minerals, mainly schist and mica, characteristic of the geologic area where the workshop is located. Small barite $\left(\mathrm{BaSO}_{4}\right)$ inclusions, a mineral found associated with the galena deposits, and lead glaze fragments related to the glaze production are also often found in the ceramic body. Finally, small crystallites of salt ( $\mathrm{NaCl}$ ) associated with contamination during burial at a place so close to the sea, are also often seen. As a consequence, the amount of sodium may be relatively high (up to $3 \% \mathrm{Na}_{2} \mathrm{O}$ ) and variable, and minor amounts of chlorine are found everywhere.

The Pechina glazes are high lead (about $60 \% \mathrm{PbO}$ ), although due to the poor state of preservation and the fact that all the sherds studied were found in the workshop debris, the lead content is quite variable (Table II). They contain also some $\mathrm{CaO}(2-5 \%)$ and aluminium $\left(1-3 \% \mathrm{Al}_{2} \mathrm{O}_{3}\right)$. The glazes show two colours: green and amber, for which $\mathrm{CuO}$ and $\mathrm{FeO}$ respectively were added. In terms of their decoration, the two most common pitcher types produced in the Pechina workshop are, on the one hand, those showing a simple incised decoration (PE62) and a bichrome glaze combination -amber outside and green inside; and secondly, a type (PE92 and PE46) showing a reticulated incised decoration outside while the inner surface is glazed in a plain greenish colour. The two most common types of serving dishes are (PE7, PE14 and PE162) with a flat base, carinated body and winged edge, and (PE66) with flat base and everted rim, show a green glaze outside and an amber glaze inside. Finally, the oil lamps show a green glaze (PE44). In summary, the most visible surfaces were decorated in green, whereas the secondary surfaces were decorated in amber.

Two underfired serving dishes (PE7 and PE162) were also analysed; in both cases the inner surface appears rather matt and opaque with a white greenish pale coloured glaze. The cross section of the glazes reveals that they are nearly fully crystallised (see Figure 5). The crystals contain lead, silicon and copper, micro-XRD identifying a lead silicate of the type $\mathrm{Pb}_{8} \mathrm{Cu}\left(\mathrm{Si}_{2} \mathrm{O}_{7}\right)_{3}$. This compound is the 
copper end member of barysilite, $\mathrm{Pb}_{8} \mathrm{X}\left(\mathrm{Si}_{2} \mathrm{O}_{7}\right)_{3}$, where $\mathrm{X}$ is $\mathrm{Mn}$ or Fe; and is produced when firing a lead glaze containing copper (manganese or iron) at relatively low temperatures, below 600-650․ $\mathrm{C}$. Therefore, their presence indicates that the glazes were fired at low temperatures. Hematite and copper oxides are also found in the glazes, showing the presence of undissolved iron and copper oxides. Finally, some weathering compounds such as cerussite, a lead carbonate $\left(\mathrm{PbCO}_{3}\right)$ typical of the alteration of the lead glaze during burial, have also been determined.

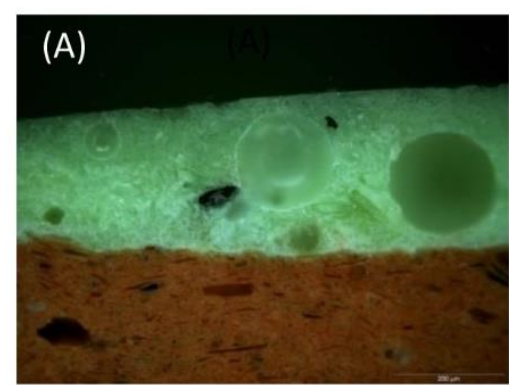

(C)

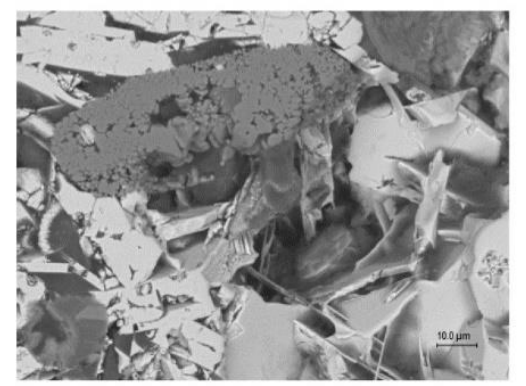

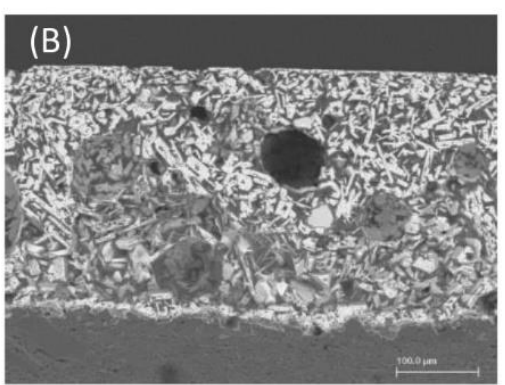

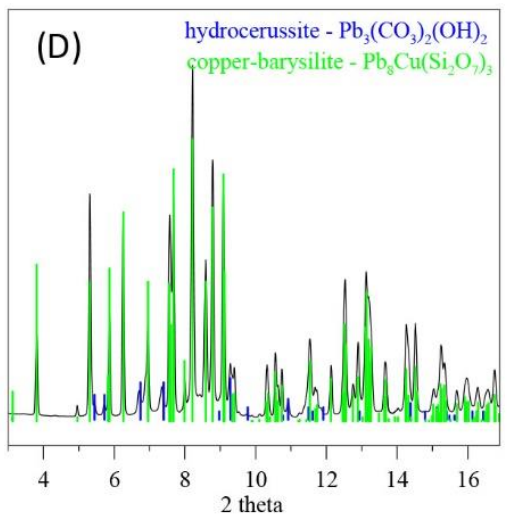

Figure 5. (A) Optical image and (B) SEM-BSE image of the cross section from the glaze from sherd PE7 showing large white crystallites, some bubbles, and copper oxides. (C) magnification of a copper oxide particle. (D) micro-XRD pattern corresponding to the white crystallites.

\subsection{Kiln furniture}

The kiln furniture, both tripods and rods, shows coarser pastes than those of the tableware. They appear partially or fully covered by green and amber glazes. The glazes are similar to those of the tableware (Table II), although containing lower lead and higher calcium and aluminium, due to the larger interaction of the bodies with the glaze, as a consequence of having been kept in the kiln at high temperature longer than the tablewares.

\subsection{Fritting vessels}

These vessels were initially identified as cooking pots by the archaeologists, but the study and analysis have demonstrated that they are actually fritting vessels. They have the same shapes as cooking pots, but they show the inner surface covered with a white clayish layer and an uneven and often rough glaze. In al-Andalus, glazed cooking pots did not begin to be used until the $12^{\text {th }}$ century. Consequently, the presence of those apparently glazed cooking pots in the workshop was most extraordinary.

Another peculiar characteristic is the presence of two different shapes (Figure 3), which correspond to different cooking pot traditions. Type I vessels are hand-made and have straight walls with 
horizontal wing-like handles; type II are wheel-thrown made and have a globular shape, narrow neck and large vertical open handles. Both shapes are related to regional pre-Islamic traditions, characteristic of Late Antiquity contexts (i.e., since the $7^{\text {th }}$ century), which had a different geographical distribution during the $8^{\text {th }}$ and $9^{\text {th }}$ centuries (Alba, Gutiérrez, 2008). The first type is found in the south-east of the Iberian Peninsula and along the Mediterranean North African coastline; the second is characteristic of the western inland region. In the region where Pechina is located, Type I vessels were the predominant cookware. Although there are not big differences between the two types, in terms of bulk analyses of the pastes, they show two different fabrics (Figure 3). Type I vessels have a calcareous clay body containing metamorphic schist inclusions as well as quartz, iron oxide pellets and mica; whereas Type II vessels again have a calcareous clay body, but containing a large amount of angular quartz grains, some quartzite and iron clay pellets. Type I vessels belonged to the local cooking pots production tradition although, in the workshop, they were used for other purposes, while Type II vessels were produced specifically for their use in the workshop. In fact, as we will demonstrate, both were used in glaze production.

The vessels were used for the preparation of the glaze; the first for fritting (Type I vessels) and the second for melting (Type II vessels) (Figures 6 and Figure 7 respectively). Both vessels appear covered inside by a white calcareous clayish layer which in its turn is covered by a glaze. Moreover, Type I vessels show also a very thin iron rich clayish layer below the white one. The composition of the glaze and of the white and iron rich layers is given in Table III.
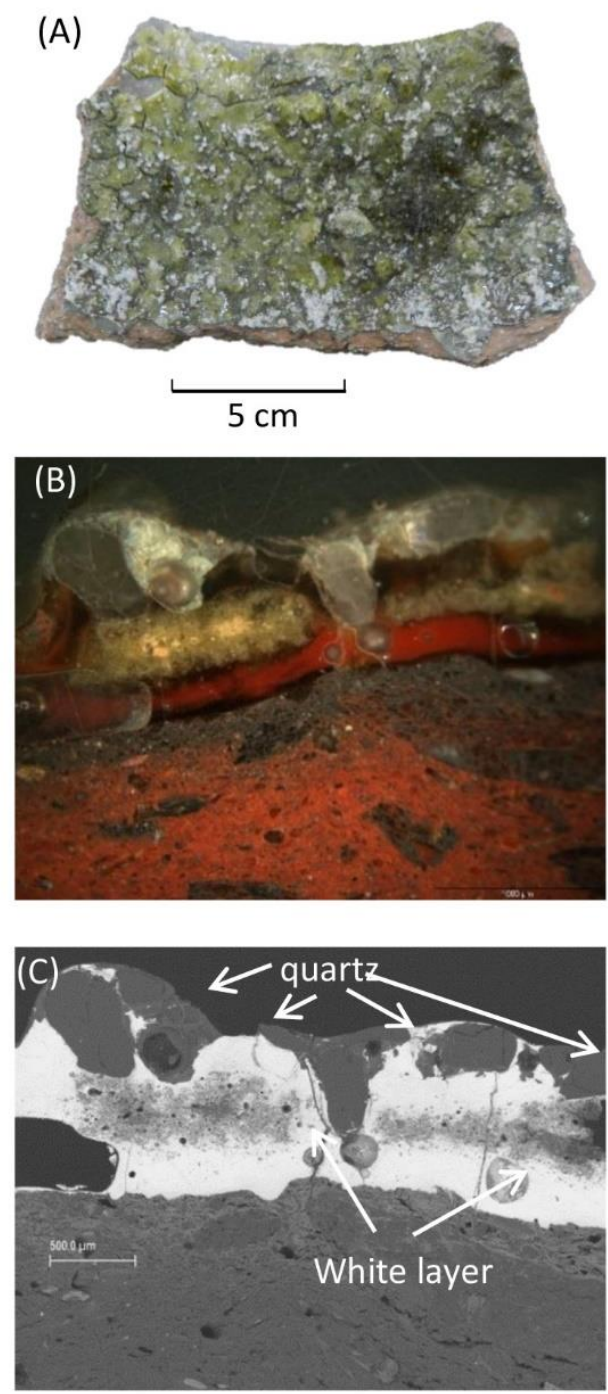
Figure 6. (A) Inner surface of Type I vessel PE158; (B) and (C) Optical and SEM-BSE image respectively of the protecting iron rich ( $\mathbf{r}$ ) and white calcareous $(\mathbf{w})$ layers, and glaze ( $\mathbf{o}$ and $\mathbf{i})$. The white calcareous layer $(\mathbf{w})$ appears partly dissolved in the glaze. Large round partly dissolved quartz grains attached to the glaze. The bright red colour of the glaze below (i) the white layer is due to the presence of small metallic copper and cuprite nanoparticles.

The white layer from Type I vessels often appears to have been largely dissolved into the glaze (Figure 6) to which large undissolved round quartz grains appear attached. The outermost layer of the glaze shows a dark amber colour and the area of the glaze below the white layer often shows a bright red colour (Figure 6). The red colour is due to the presence of small cuprite and metal copper nanoparticles formed due to the reducing conditions to which those areas of the glaze are exposed during the firing. The white layer is a calcareous clay and the iron rich layer is a iron-rich noncalcareous clay.

In contrast, Type II vessels show a thicker white layer, the reaction with the glaze being limited and the presence of more than one glaze (above and below the layer) often being observed; this is due to the penetration of the melt through cracks in the white layer (Figure 7). The glazes are greenish and show also patched red areas. The existence of those red patched areas in the glazes has also been found in other contemporary tableware productions (Salinas, Pradell 2018) due to the presence of metal copper nanoparticles.
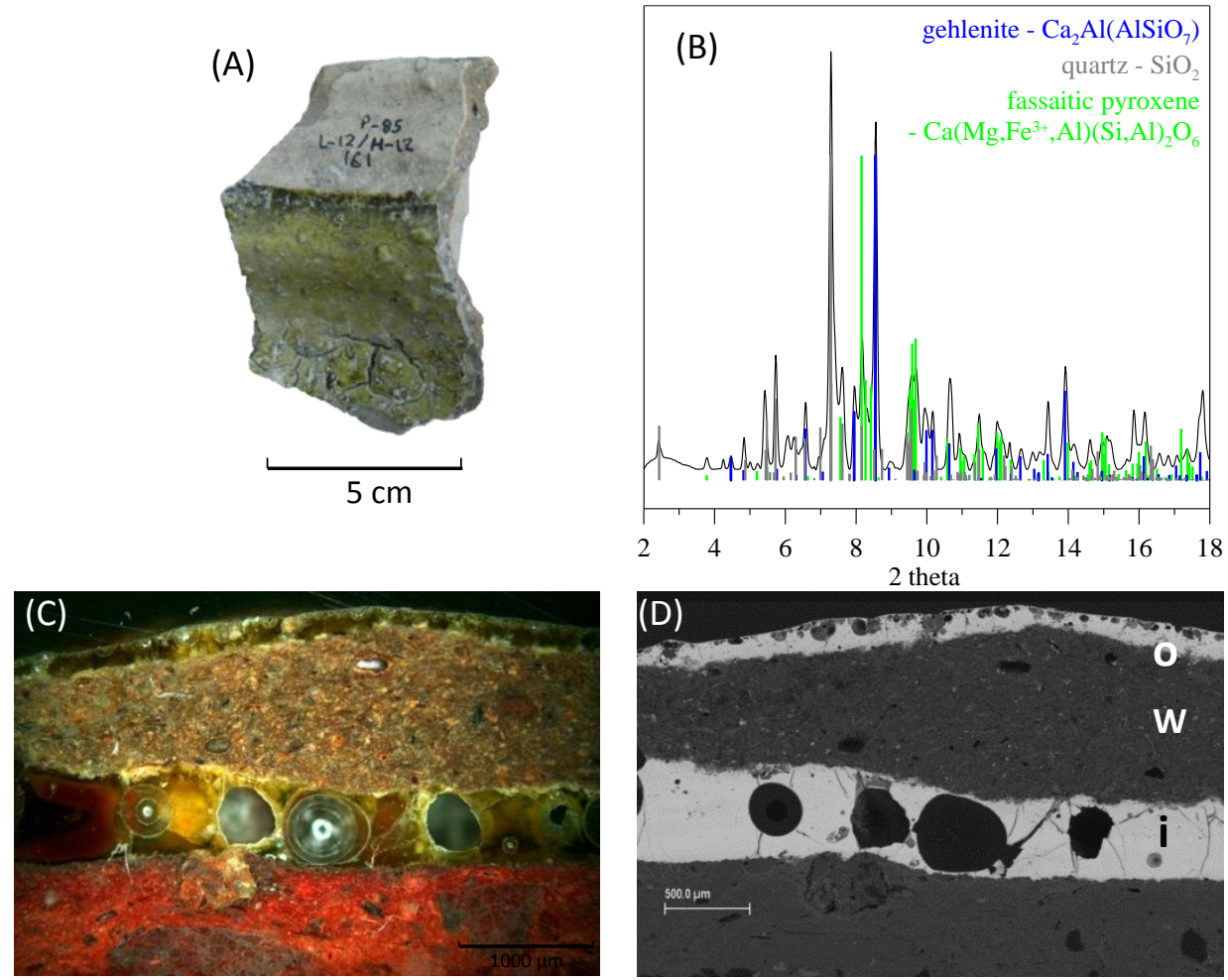

Figure 7. (A) Inner surface of Type II vessel PE17. (B) XRD pattern of the white calcareous clayish layer (w). (C) and (D) Optical and SEM-BSE image of the white layer (w) and glazes (o) (i). The penetration of the glaze through cracks is clearly seen. The colour of the glaze is greenish but it shows in some bright red areas due to the presence of metallic copper and cuprite nanoparticles.

The white clayish layer is a calcareous clay containing illite, gehlenite and a fassaitic pyroxene (Table I and Figure 7). The complete absence of calcite and the presence of gehlenite indicate a firing temperature above $800^{\circ} \mathrm{C}$, while the presence of illite indicates a firing temperature below 1000 으. 
Moreover, the presence of fassaitic pyroxenes and absence of calcium feldspars agrees with a firing temperature of about $900-950$ 으.

Consequently, the white layer is most probably a protecting layer to avoid the molten glazes sticking on the inner surface of the pots. The iron rich layer purpose is not so obvious, it is very thin, and therefore, it is most probably the outside finishing of the pots (the potter usually apply some clay slurry to smooth the surface).

The glaze is a high lead glaze containing mainly calcium and aluminium dissolved from the white clay layer into the glaze during the firing.

The presence of unreacted or half-melted large quartz grains, attached to the glaze, and the composition of the glaze suggests that a frit consisting of a mixture of lead oxide and quartz sand was made inside Type I vessels. This frit, which was never fully molten in this first stage, was then ground finely and placed into a Type II vessel where it was melted. The wetting mark present in neck of the Type II vessels (see Figure 7) demonstrates the melting of the glaze mixture inside. The globular shape of these vessels is more appropriate for obtaining a more homogeneous temperature inside the vessel, and the narrow neck and open handles are suitable for holding the vessel and pouring the melt. In contrast, the larger size and thicker walls of Type I vessels made them more appropriate for the first fritting stage, where a larger volume of a coarser material was fired.

Consequently, the two vessels were used for each of the two stages of the glaze production: (I) fritting of a lead oxide and quartz sand mixture in the straight vessels and (II) melting of the mixture in the globular vessels.

\subsection{Slags and glass chunk}

A collection of numerous slag fragments was found in the archaeological excavation concentrated in an area close to the kilns. They were found either in the dump area of the workshop, or filling the walls of the houses of the next phase of excavation.

The slags are black glasses and most of them are shapeless (SL381 to PSL384), although two large pieces were also found, one being convex (SL385) and the other flat (SL340). All the slags show a similar composition and microstructure, in spite of some differences (Table IV). The slags are calcium $(13-18 \% \mathrm{CaO})$ and iron rich $(10-18 \% \mathrm{FeO})$, and contain between $5 \%$ and $8 \% \mathrm{Al}_{2} \mathrm{O}_{3}$, between $5 \%$ and $8 \% \mathrm{PbO}$ and a little sulphur $\left(0.2-0.4 \% \mathrm{SO}_{3}\right)$.

The slags are of a glassy nature but contain undissolved quartz grains (Figure $\mathbf{8 C}$ ), micro-crystallite growths (Figure $\mathbf{8 D}$ ) and submicrometric spherical precipitates (Figures $\mathbf{8 E}$ and $\mathbf{8 F}$ ). The microcrystallite composition $\left(10.9 \% \mathrm{MgO}, 5.9 \mathrm{Al}_{2} \mathrm{O}_{3}, 44.7 \mathrm{SiO}_{2}, 1.8 \% \mathrm{P}_{2} \mathrm{O}_{5}, 0.5 \% \mathrm{~K}_{2} \mathrm{O}, 22.6 \% \mathrm{CaO}\right.$ and $11.9 \% \mathrm{FeO}$ ) indicates that they are iron rich pyroxenes (Figure $8 \mathrm{D}$ ). The submicrometric spherical precipitates are of a more heterogeneous nature, the most common containing mainly $\mathrm{Cu}, \mathrm{S}$ and $\mathrm{Pb}$ (typical composition $20.1 \% \mathrm{SO}_{3}, 3.5 \% \mathrm{CuO}$ and $72.7 \% \mathrm{PbO}$ ), and being associated with a mixture of $\mathrm{PbS}$ and $\mathrm{Cu}_{2} \mathrm{O}$ where, in Figure $8 \mathrm{~F}$, the light area corresponds to $\mathrm{PbS}$ and the grey area to $\mathrm{Cu}_{2} \mathrm{O}$. However, other spherical precipitates contain metallic copper, metallic lead and also antimony, silver and arsenic (see Figure $\mathbf{8} \mathbf{G}$ and Figure $\mathbf{8 H}$ ), although they cannot be fully analysed, partly because they appear as very small spots, and partly because they are below the limits of detection of the EDS in the bulk analysis of the slags.

Although copper cannot be located macroscopically, in fact there is a lot of copper concentrated in the small spherical precipitates together with lead and sulphur. They seem to be related to some processing of galena lead ore $(\mathrm{PbS})$, most probably as a result of the process of oxidation of galena 
to obtain lead oxide $(\mathrm{PbO})$. The reaction between the ore and the ceramic container would produce a calcium and aluminium rich glass slag. The presence of the small precipitates of lead sulphide is related to the presence of sulphur, which is not completely removed in the oxidative process. The presence of barium, zinc, silver and antimony are related to galena ores. Small fragments of barite $\left(\mathrm{BaSO}_{4}\right)$, a mineral associated with galena, are also often found in the ceramic bodies of the wares.
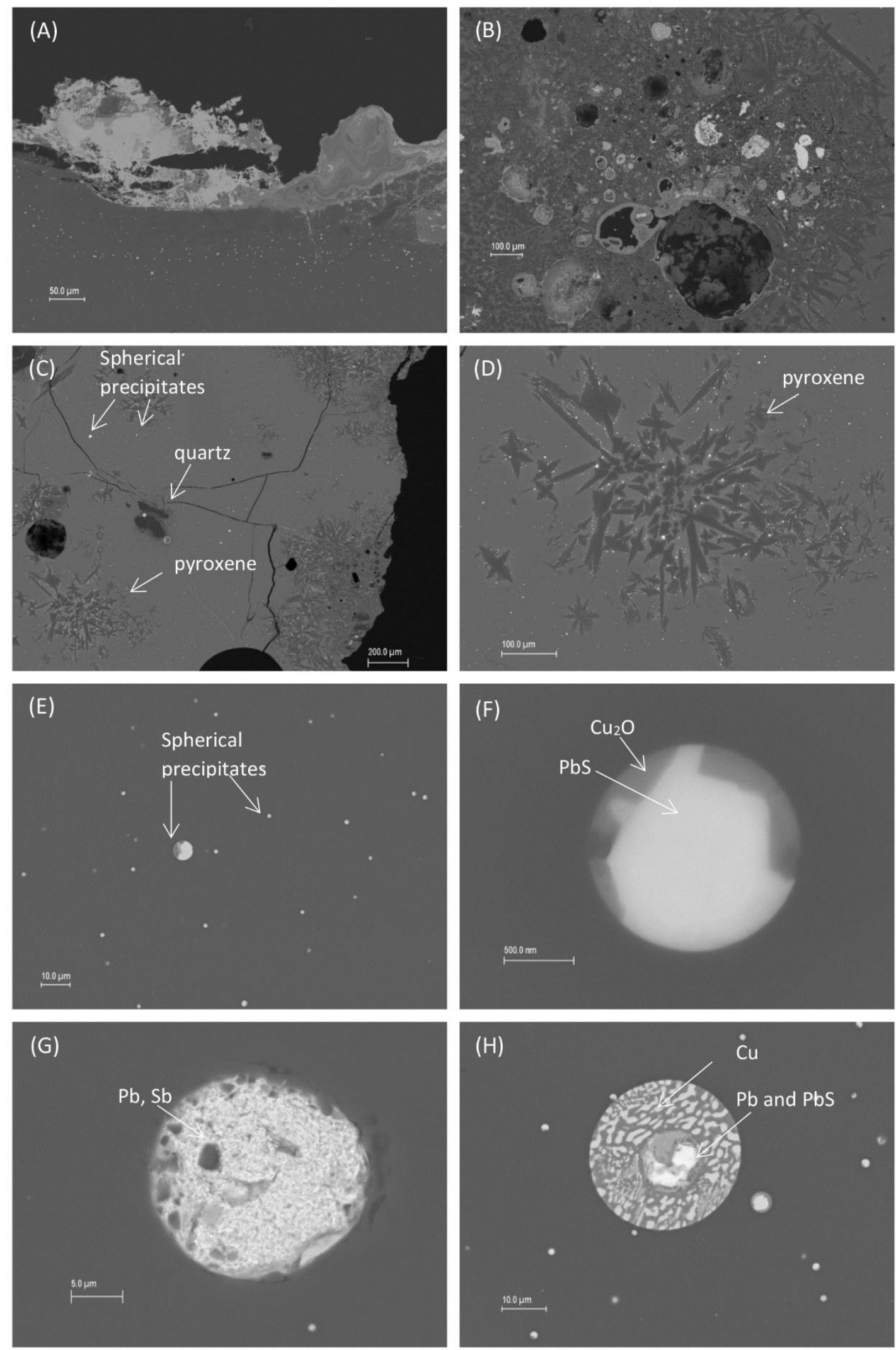
Figure 8. SEM-BDS images of (A) SL384 showing the presence of metal attached and small spherical precipitates, (B) SL381 showing copper rich, lead rich particles and growing pyroxene crystallites (C) SL383 showing the presence of bubbles, undissolved quartz grains, pyroxene crystallites and small spherical precipitates; (D) magnification of a pyroxene surrounded by small spherical precipitates; (E), (F) and (G) magnification of the small spherical precipitates from SL381 containing lead sulphide and cuprite and lead oxide with some antimony and $(\mathrm{H})$ magnification of a small spherical precipitate containing lead sulphide and metallic copper from SL385.

On the other hand, a glass chunk (SL30) was documented. It exhibits a brown colour, darker near the side which is flat, and has an iridescent surface (SL3ON). The other side, which is convex and has soil attached, shows a lighter reddish colour and is more opaque (SL3OR) (Figure 4C and Figure 9A and Figure 9B). The chemical composition (Table III) of the glass, which has a high lead content with some aluminium and calcium, corresponds perfectly well with those of the glazes applied to the tableware ceramics and with the glazes attached to the frit ware. The reddish opaque colour of the glass is related to the presence of cuprite nanoparticles, which are larger and, therefore, can be clearly seen with a reddish colour (Figure 9C and Figure 9D).

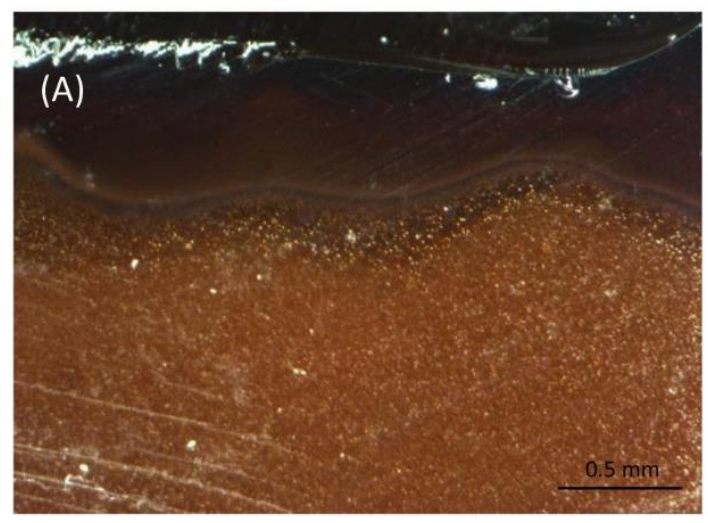

(B)
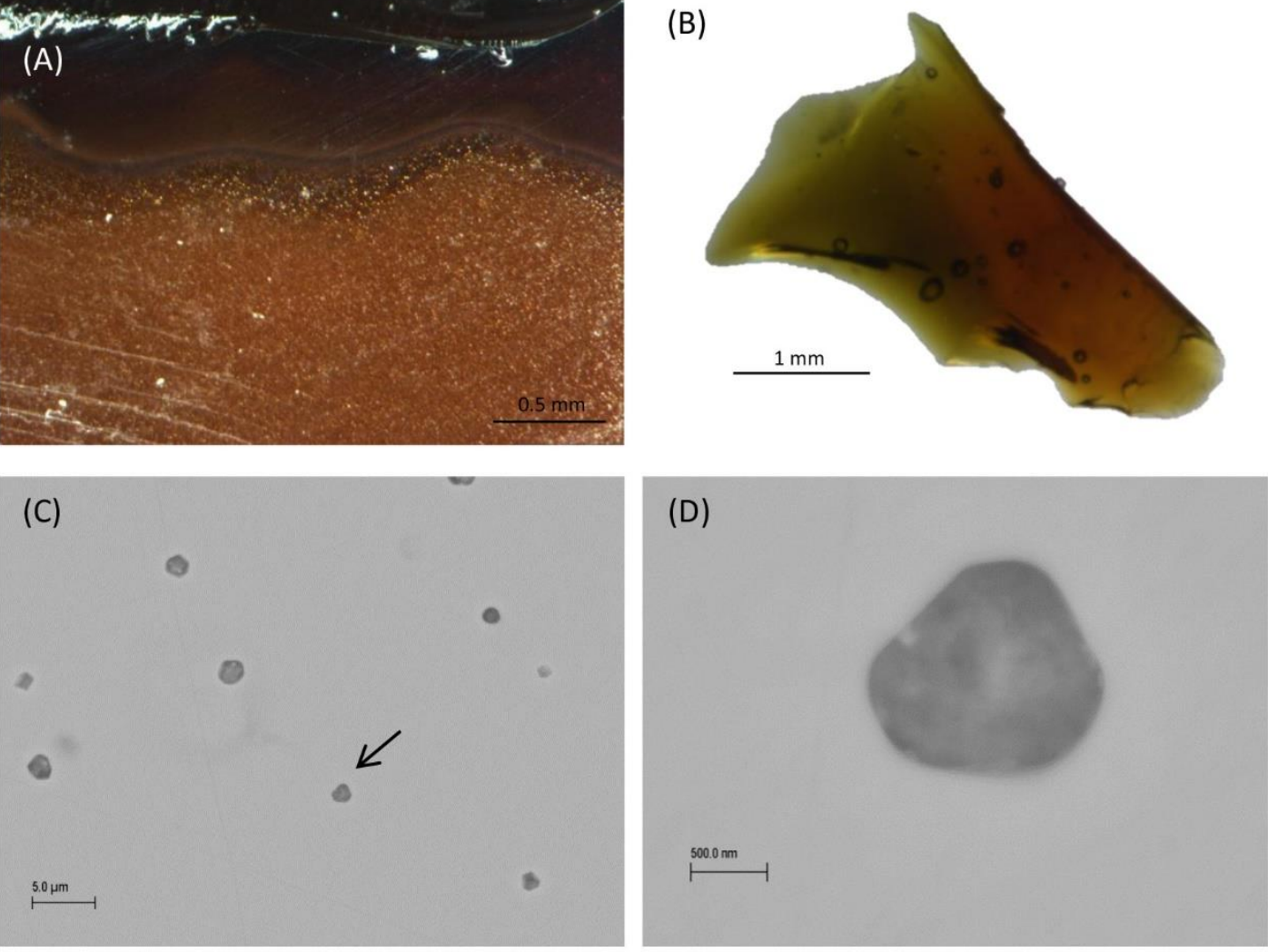

Figure 9. Optical images of $(A)$ the glass chunk section showing the dark brown transparent (db) (SL3ON) and the reddish opaque ( $\mathbf{r}$ ) (SL3OR) areas and (B) of flat, dark brown surface of glass chunk of SL30 (SL30N) sample. SEM BSE images of (C) SL3OR and (D) magnification of the cuprite nanoparticle marked with an arrow. 


\section{DISCUSSION}

The analyses of the materials found in the workshop allow us to unravel the processes in the production of the glazed wares. The presence of unglazed wasters allows us to confirm that the wares were biscuit fired previous to the application of the glaze.

For the preparation of the glaze mixture, the first step was to oxidize galena ( $\mathrm{PbS}$ ) to obtain $\mathrm{PbO}$. Roasting of galena gives rise to the formation of lead sulphate $\left(\mathrm{PbSO}_{4}\right)$ at low temperatures $\left(300^{\circ} \mathrm{C}\right)$, and various oxysulphates and lead oxide at higher temperatures $\left(\mathrm{PbSO}_{4} \cdot \mathrm{PbO}\right.$ at $600^{\circ} \mathrm{C}, \mathrm{PbSO}_{4} \cdot 2 \mathrm{PbO}$ at $800^{\circ} \mathrm{C}$ and $\mathrm{PbSO}_{4} \cdot 4 \mathrm{PbO}$ at $900^{\circ} \mathrm{C}$ ) while lead oxide $(\mathrm{PbO})$ is the ultimate phase at $1000^{\circ} \mathrm{C}$ (AbdelRehim 2006). Consequently, galena had to be roasted in the open air at high temperature to obtain $\mathrm{PbO}$. This should be performed in an open vessel (the possible crucible, Figure 2G, had $40 \mathrm{~cm}$ diameter) to ensure aeration; stirring the mineral would also help to complete the oxidation process. The small furnace found in the workshop had space for a single pot and it was designed (Thiriot 1997) to have an opening for introducing a handle to stir the material inside. Moreover, the size and shape (open flat) of the possible crucible match the kiln chamber diameter.

Lead oxide was afterwards mixed with crushed sand (basically quartz grains) and introduced into the Type I fritting vessels where the large quartz grains were partly dissolved by the formation of a melt with a composition ranging between $70 \% \mathrm{PbO}$ and $90 \% \mathrm{PbO}$ at temperatures between $717^{\circ} \mathrm{C}$ and $760^{\circ} \mathrm{C}$ [FactSage 2018; Di Febo et al. 2017]. The sandy material obtained was ground and introduced into the Type II vessels where, probably after adding some more $\mathrm{PbO}$, the material was melted. The liquid was poured onto a flat surface or into a pit full of water and a high lead glass (about $70 \% \mathrm{PbO}$ ) was obtained. Then the glass was ground and mixed with water and probably some binding material (i.e. Arabic gum, clay) and applied on the surfaces of the biscuit fired vessels. Then the vessels were fired again to soften the glass and adhere it onto the ceramic surface. The firing temperature can be estimated as those at which the glass flows again and which may be calculated from the composition of the glass (Flugel 2007) to be $642^{\circ} \mathrm{C}$. This temperature is lower than those necessary to melt an equivalent mixture of lead oxide and quartz, $717^{\circ} \mathrm{C}$. The time necessary to allow the reaction of solid quartz particles with the lead oxide is also longer than those of the glass flowing. Consequently, both firing temperature and time are reduced if a fritted lead glaze instead of the raw compounds is applied.

The glass chunk found in the workshop already contains copper. Therefore, the glass could be used directly to produce a green glaze. Nevertheless, in some of the low fired glazes, iron oxide or copper oxide particles have also been identified (Figure 5C). Consequently, it is also probable that the colourants were added to the glaze mixture.

Fritting vessels and a glass chunk have been analysed from the San Nicolas workshop (Murcia), also located in al-Andalus, which was working during the Caliphal period. Two types of fritting vessels with similar shapes to Pechina types, and also showing an inner surfaces covered with a white calcareous clay layer were again used (Molera et al 2008). Moreover, a glass chunk with a composition similar to those of the lead glazed wares was found in the area. All this suggests that the same glazing technique persisted into the $10^{\text {th }}$ century. Nevertheless, the glass and glazes from San Nicolas appear to be poorer in lead ( $58 \%$ and $55 \%$ PbO respectively) than those found in Pechina. Finally, no fritting vessels have been documented in the Andalusi workshops from the Almohad period $\left(12^{\text {th }}-13^{\text {th }}\right.$ centuries $)$.

Tracing the possible connections with other Islamic glaze production centres, slags and crucibles possibly related to the glaze technology have been found but have not been analysed (e.g., dating to the $10^{\text {th }}$ century in Fustat) (Gayraud, Vallaury 2017). Furnaces directly related to glaze production have not yet been identified in the early Islamic period. Nevertheless, some later parallels to the 
kiln with a small circular chamber found in Pechina have been identified in later workshop areas, such as Marseille (13 ${ }^{\text {th }}$ century), and Tunisia and Pakistan (20 $0^{\text {th }}$ century) (Thiriot 1997$)$.

With regard to the kiln furniture, in contrast to what is found in Pechina, tripods have not been uncovered in early Islamic workshops. Instead in the late $8^{\text {th }}$-early $9^{\text {th }}$ centuries Raqqa craft areas, rings instead tripods are found (François, Shaddoud 2013). The use of tripods is not documented in the Islamic workshops found so far until later in Susa and Fustat (10 ${ }^{\text {th }}$ century), as well as in the Byzantine world (12 $2^{\text {th }}$ century) (François, 2005). Finally, unglazed plain, straight, cylindrical rods completely different from those found in Pechina, were used as kiln bars in the $8^{\text {th }}$ and $9^{\text {th }}$ centuries at Islamic workshops such as Raqqa (François, Shaddoud 2013) and Basra (Mason, Keall 1991). Rods, also showing some turquoise enamel drops, were found in later workshops (Fustat, late $10^{\text {th }}$ century) (Gayraud, Vallaury 2017).

Finally, concerning the production of early Islamic high-lead glazes, they are documented in Syria and Egypt, at least since the $8^{\text {th }}$ century, with the Yellow Glaze Family and Coptic Glazed Ware respectively. However, they were lead stannate opacified, not transparent glazes (Tite et al 2015). Moreover, during the ninth century Iraqi workshops also produced both amber-brown (52-60\% $\mathrm{PbO}$ ) and green (41-56\% PbO) high lead glazes (Wood et al 2009). In contrast, contemporary green and brown polychrome transparent glazes of the Aghlabid Ifriqiya have lower lead contents (36$51 \% \mathrm{PbO}$ ) (Ben Amara et al 2001).

\section{CONCLUSIONS}

To summarise, the production of glazed ceramic in al-Andalus, in the second half of the $9^{\text {th }}$ century, involves the utilisation of a new technology. The earliest workshop found so far has been discovered in Pechina where new tableware types, mainly pitchers, jugs and serving dishes, different from the previous tradition were produced. The kiln structures, kiln furniture (tripods and rods), fritting vessels, wasters, slags and a glass chunk have been studied in addition to the tableware. The ceramics were wheel thrown and biscuit fired prior to the application of a transparent high lead glaze with copper green and iron amber colours. The slags provide direct evidence of the oxidation of galena $(\mathrm{PbS})$ to obtain lead oxide ( $\mathrm{PbO}$ ) which was probably performed in the small kiln found in the workshop. Two different types of vessels were used for the preparation of the glaze; the first type has straight walls and horizontal wing-like handles, and was used for fritting, but not necessarily fully melting, a mixture of lead oxide and quartz sand. The second type, subsequently used to produce a melt, has a globular shape, narrow neck and large vertical open handles, which facilitated pouring the melt to obtain a glass. Both fritting vessels appear covered inside by a protecting white calcareous clayish layer which added mainly calcium and aluminium to the glass composition. The existence of underfired glazes demonstrate that the high lead glass was ground and applied over the biscuit fired ceramics which were then fired to a temperature high enough to soften the glaze and adhere it onto the ceramic surface. Evidences of a similar process were found in a later workshop in San Nicolas (10 $10^{\text {th }}$ century) which demonstrates the persistence of the technique in al-Andalus during the caliphal period (Molera et al 2009).

A very limited number of contemporary Islamic workshops have been found (Raqqa and Basra) and none have yet been analysed. The kiln furniture documented so far is different from those found in Pechina. Nevertheless, similar high lead glazes are documented in Iraq since the beginning of the $9^{\text {th }}$ century. 


\section{Acknowledgements}

Elena Salinas is funded by the Marie Skłodowska-Curie Actions call H2020-MSCA-IF-2015 project IGATO. We are grateful to the funds received from Ministerio de Ciencia e Innovación (Spain) project MAT2016-N0748719-R and Generalitat de Catalunya project 2017 SGR 00042. The $\mu$ SRXRD experiments were performed at BL04 MSPD beamline at ALBA Synchrotron Facility with the collaboration of ALBA staff. We would also thank Francisco Castillo, Rafael Martínez and Manuel Ramos for their helpful contribution and access to the material and information.

\section{References}

Abdel-Rehim, A.M., 2006. "Thermal and XRD analysis of egyptian galena", Journal of Thermal Analysis and Calorimetry, 86 (2), 393-401.

Acién, M., Castillo, F., Martínez, R., 1990. "Excavación de un barrio artesanal de Bayyana (Pechina, Almería)", Archéologie islamique, 1, 147-168.

Alba, M., Gutiérrez, S., 2008. "Las producciones de transición al Mundo Islámico: el problema de la cerámica paleoandalusí (siglos VIII y IX)", Cerámicas hispanorromanas: un estado de la cuestión. Cádiz, 585-616.

Ben Amara, A., Schvoerer, M., Daoulatli, A., Rammah, M., 2001. "Jaune de Raqqada" et autres couleurs de céramiques glaçurées aghlabides de Tunisie (IX - X siècles), Revue d'Archéométrie, 25, 179-186.

Cara, L., 2011. Pechina. Historia y Memoria. Almería: Instituto de Estudios Almerienses.

Castillo, F., Martínez, R., Acién, M., 1987. "Urbanismo e industria en Bayyana. Pechina (Almería)", Actas del II C.A.M.E., II. Madrid, 539-548.

Castillo, F., Martínez, R., 2000. "Un taller de vidrio en Baŷŷāna-Pechina (Almería)". El vidrio en alAndalus. Madrid, 83-101.

Coll, J., García, A., 2010. "Tipologia, cronologia e produzione dei forni per cerámica in Al-Andalus", Atti. XLII Convegno internazionale della ceramica, Albisola, 25-44.

Factsage. Phase diagram PbO-SiO2. http://www.crct.polymtl.ca/fact/phase diagram.php?file=PbSi-O PbO-SiO2.jpg\&dir=FToxid, Accessed March 14, 2018.

Flugel, F., 2007. "Glass viscosity calculation based on a global statistical modelling approach", Europ. J. Glass Sci. Tech. A 48[1] 13-30.

François, V., 2005. "La vaisselle de table à Byzance: un artisanat et un marché peu perméables aux influences extérieures". M. Balard, E. Malamut, J.M. Spieser. Byzance et le monde extérieur. Contacts, relations, échanges, 21, Publications de la Sorbonne, 211-223.

François, V, Shaddoud, I., 2013. "Nouvel atelier de potier d'époque abbasside au sud de Tell Abou Ali à Raqqa", al-Rāfidān, vol. XXXIV, 21-79.

François, V., Spieser, J.M., 2002. "Pottery and Glass in Byzantium". The Economic History of Byzantium. From the Seventh through the Fifteenth Century. A. Laiou. Washington D.C., Dumbarton Oaks Research Library and Collection. I: 593-610.

Freestone, I.C., Jackson-Tal, R.-E., Taxel, I., Tal, O., 2015. "Glass production at an Early Islamic workshop in Tel Aviv", Journal of Archaeological Science, 62, 45-54. 
Gayraud, R.-P., Vallauri, L., 2017. Fustat II. Fouilles d'Isțabl 'Antar. Céramiques d'ensembles des IXe et $X^{e}$ siècles. Institut français d'archéologie orientale. Fouilles de I'Ifao 75/Institut d'Archéologie Orientale, Le Caire.

Gragueb, S., 2017. "La céramique aghlabide de Raqqada et les productions de l'Orient islamique: parenté et filiation", The Aghlabids and their Neighbors: Art and Material Culture in Ninth-century North Africa, Brill. Arts and Archaeology of the Islamic World serie. Leiden, 341-361.

Hallett, J., 1990. "Imitation and Inspiration: the ceramic trade from China to Basra and back". UNESCO Maritime Silk Roads Expedition, Goa Conference. www.Unesco.org

Larrea, I., 2008. Memoria preliminar de la A.A.Pre en el E.D. SC3-Zumbacón (Córdoba) (unpublished work).

Mason, R.B., Keall, E.J., 1991. "The 'Abbāsid Glazed Wares of Sirrāf and the Bașra Connection: Petrographic Analysis". Iran, 29, 51-66.

Matin, M., 2016. Revisiting the Origins of Islamic Glazed Pottery: A Technological Examination of 8th-10th Century AD Ceramics from Islamic Lands. PhD thesis (unpublished work).

McPhillips, S., 2012. "Continuity and innovation in Syrian artisanal traditions of the $9^{\text {th }}$ to $13^{\text {th }}$ centuries". Bulletin d'études orientales, tome LXI, 447-473.

Molera, J., Pradell, T., Salvadó, N., Vendrell-Saz, M., 2009. "Lead Frits in Islamic and Hispanomoresque Glazed Productions". From Mine to Microscope. Advances in the Study of Ancient Technology. Oxford, Oxbow, 11-22.

Salinas, E., Montilla, I., 2017. "Material-culture interactions between al-Andalus and the Aghlabids". The Aghlabids and their Neighbors: Art and Material Culture in Ninth-century North Africa, Brill. Arts and Archaeology of the Islamic World serie. Leiden, 429-447.

Tite M., Watson O., Pradell T., Matin M., Molina G., Domoney K., Bouquillon A., 2015. "Revisiting the beginnings of tin-opacified Islamic glazes". Journal of Archaeological Sciences 57, 80-91.

Thiriot, J., 1997. "Les fours pour la préparation des glaçures dans le monde méditerranéen". Actes du VIe Congrès de l'AIECM2. Aix-en-Provence, 513-522.

Watson, O., 1999. "Report on the glazed ceramics", in P. Miglus (ed.), Ar-Raqqa I. Die Frühislamische Keramik von Tall Aswad. Mainz, 81-87, taf. 94-99.

Watson, O., 2014. Revisiting Samarra: the rise of the Islamic glazed pottery. Beiträge Zur Islamischen Kunst Und Archäologie, 4, 125-144.

Wood, N., Doherty, C., Owen, M. R., 2009. "A Technological Study of Iraqi Copies of Chinese Changsha and Chinese Sancai Wares found at Samarra", Gu Taoci Kexue Jishu 8: ISAC '09. Beijing, 154-180. 
Table I. Analyses of the ceramic bodies of the wares and fritting vessels.

\begin{tabular}{ccccccccccc}
\hline Type & Sample & $\mathrm{Na}_{2} \mathrm{O}$ & $\mathrm{MgO}$ & $\mathrm{Al}_{2} \mathrm{O}_{3}$ & $\mathrm{SiO}_{2}$ & $\mathrm{~K}_{2} \mathrm{O}$ & $\mathrm{CaO}$ & $\mathrm{TiO}_{2}$ & $\mathrm{FeO}$ & $\mathrm{PbO}$ \\
\hline tripod & PE3 & 1.8 & 2.3 & 16.2 & 45.9 & 3.3 & 22.3 & 0.7 & 6.1 & 0.2 \\
\hline rod & PE55 & 1.8 & 1.9 & 18.5 & 56.4 & 2.9 & 9.9 & 1.0 & 7.6 & \\
\hline fritting vessel & PE12 & 1.1 & 1.5 & 19.7 & 60.4 & 3.4 & 1.8 & 0.9 & 9.9 & 1.1 \\
type I & PE158 & 0.8 & 1.5 & 19.2 & 64.4 & 3.3 & 1.1 & 0.9 & 8.5 & \\
\hline \multirow{4}{*}{ fritting vessel } & PE17 & 1.3 & 1.1 & 15.2 & 70.1 & 3.8 & 1.7 & 0.5 & 5.0 & 1.1 \\
type II & PE21 & 1.4 & 1.8 & 20.0 & 61.1 & 3.6 & 1.8 & 1.5 & 8.8 & \\
& PE61 & 1.6 & 2.1 & 19.0 & 55.1 & 3.5 & 2.5 & 2.3 & 7.9 & 5.8 \\
& PE166 & 1.6 & 1.7 & 23.6 & 56.9 & 4.5 & 1.5 & 0.6 & 8.5 & \\
& PE97 & 0.9 & 1.9 & 15.6 & 68.5 & 2.9 & 1.7 & 1.2 & 7.0 & \\
\hline \multirow{4}{*}{ pitcher } & PE62 & 2.4 & 3.5 & 18.3 & 47.1 & 4.41 & 16.3 & 0.7 & 5.9 & \\
& PE46 & 2.9 & 3.5 & 18.1 & 48.7 & 4.19 & 15.5 & 0.8 & 6.0 & \\
& PE92 & 3.1 & 2.4 & 18.2 & 50.8 & 0.8 & 15.4 & 0.8 & 6.8 & 1.6 \\
\hline \multirow{4}{*}{ dish } & PE14 & 1.4 & 2.2 & 15.9 & 47.0 & 3.0 & 20.6 & 0.7 & 6.9 & 1.5 \\
& PE66 & 1.8 & 8.5 & 16.2 & 45.2 & 3.2 & 14.1 & 0.6 & 5.6 & 2.3 \\
& PE7 & 1.4 & 5.0 & 16.1 & 48.6 & 3.5 & 15.9 & 0.7 & 5.8 & 1.9 \\
& PE162 & 2.0 & 2.5 & 15.9 & 47.9 & 3.7 & 17.3 & 0.8 & 5.8 & 2.2 \\
\hline lamp & PE44 & 3.2 & 3.2 & 17.9 & 46.5 & 0.9 & 16.9 & 0.7 & 6.6 & 3.3 \\
\hline
\end{tabular}


Table II. Analyses of the glazed wares and wasters. g: green glaze. a:amber glaze. i: inner surface. o: outer surface

\begin{tabular}{|c|c|c|c|c|c|c|c|c|c|c|c|c|c|c|}
\hline Type & Sample & Glaze & Side & $\mathrm{Na}_{2} \mathrm{O}$ & $\mathrm{MgO}$ & $\mathrm{Al}_{2} \mathrm{O}_{3}$ & $\mathrm{SiO} 2$ & $\mathrm{~K}_{2} \mathrm{O}$ & $\mathrm{CaO}$ & $\mathrm{TiO}_{2}$ & $\mathrm{FeO}$ & $\mathrm{CuO}$ & $\mathrm{ZnO}$ & $\mathrm{PbO}$ \\
\hline tripod & PE3 & g & & 0.6 & 0.9 & 3.8 & 26.1 & 1.1 & 4.8 & 0.2 & 2.4 & 1.1 & & 58.9 \\
\hline rod & PE55 & $\mathrm{g}$ & & 0.6 & 0.6 & 4.7 & 31.9 & 1.5 & 2.8 & 0.1 & 1.7 & 1.2 & 0.2 & 54.6 \\
\hline \multirow{5}{*}{ pitcher } & \multirow{2}{*}{ PE62 } & $g$ & $\mathrm{i}$ & 0.5 & 0.7 & 3.5 & 28.6 & 0.6 & 3.0 & & 2.0 & 1.1 & & 60.0 \\
\hline & & a & 0 & 0.5 & 0.7 & 4.7 & 23.7 & 0.9 & 3.4 & & 3.9 & 0.2 & & 62.4 \\
\hline & \multirow{2}{*}{ PE46 } & g & $\bar{i}$ & 0.8 & 0.8 & 3.2 & 37.9 & 1.2 & 2.9 & & 2.1 & 0.9 & & 50.9 \\
\hline & & $\mathrm{a}$ & 0 & 0.7 & 0.7 & 2.0 & 35.9 & 1.1 & 2.2 & & 5.4 & 0.3 & 0.3 & 51.8 \\
\hline & PE92 & $a$ & $\mathrm{i}$ & 1.4 & 0.9 & 4.1 & 30.2 & 1.8 & 5.0 & & 1.9 & 0.0 & & 54.7 \\
\hline \multirow{6}{*}{ dish } & \multirow{2}{*}{ PE14 } & g & $\mathrm{i}$ & 0.5 & 0.5 & 3.2 & 25.9 & 0.9 & 3.8 & 0.4 & 1.3 & 4.1 & & 59.6 \\
\hline & & a & 0 & 0.6 & 0.4 & 2.2 & 27.3 & 0.9 & 3.1 & & 4.1 & 0.0 & & 61.6 \\
\hline & \multirow{2}{*}{ PE66 } & g & $\mathrm{i}$ & 0.9 & 0.4 & 2.7 & 24.7 & 0.7 & 2.7 & 0.4 & 1.4 & 1.3 & & 63.5 \\
\hline & & a & 0 & 0.7 & 0.6 & 1.7 & 24.4 & 0.7 & 1.8 & 0.4 & 2.1 & 0.5 & & 68.3 \\
\hline & PE7 & $\mathrm{a}$ & 0 & 0.6 & 0.4 & 1.6 & 24.5 & 0.7 & 1.6 & & 2.9 & 0.2 & & 67.4 \\
\hline & PE162 & $a$ & 0 & 0.8 & 0.8 & 2.5 & 25.1 & 0.4 & 3.2 & & 3.3 & 0.6 & & 63.2 \\
\hline \multirow{2}{*}{ lamp } & \multirow{2}{*}{ PE44 } & $g$ & $i$ & 1.5 & 0.7 & 3.1 & 32.6 & 1.6 & 3.7 & & 1.7 & 1.3 & & 54.0 \\
\hline & & g & 0 & 1.3 & 0.7 & 3.6 & 27.8 & 1.3 & 4.6 & 0.2 & 1.9 & 1.8 & & 56.7 \\
\hline
\end{tabular}


Table III. Analysis of protection and glaze layers inside the fritting vessels. Inner surface of the vessels, o: outside glaze; $w$ : white calcareous layer; $\mathrm{w}^{*}$ the layer is partly dissolved in the glaze; i: inside glaze; r: iron rich layer. Outside surface of the vessel, d: glaze drop.

\begin{tabular}{|c|c|c|c|c|c|c|c|c|c|c|c|c|c|}
\hline Type & Sample & Side & $\mathrm{Na}_{2} \mathrm{O}$ & $\mathrm{MgO}$ & $\mathrm{Al}_{2} \mathrm{O}_{3}$ & $\mathrm{SiO}_{2}$ & $\mathrm{~K}_{2} \mathrm{O}$ & $\mathrm{CaO}$ & $\mathrm{TiO}_{2}$ & $\mathrm{FeO}$ & $\mathrm{CuO}$ & $\mathrm{ZnO}$ & $\mathrm{PbO}$ \\
\hline \multirow{7}{*}{ Type I } & \multirow{3}{*}{ PE12 } & 0 & 1.1 & 0.2 & 1.2 & 27.4 & 0.4 & 1.5 & 0.0 & 0.4 & 0.2 & & 67.6 \\
\hline & & w & 2.7 & 3.7 & 16.2 & 45.0 & 1.1 & 17.8 & 0.6 & 6.3 & & & 6.0 \\
\hline & & $r$ & 4.7 & 1.8 & 22.6 & 51.5 & 4.8 & 1.9 & 0.4 & 9.8 & & & 2.3 \\
\hline & \multirow{4}{*}{ PE158 } & 0 & 0.9 & 0.5 & 2.4 & 28.7 & 0.5 & 1.8 & 0.3 & 1.01 & 0.4 & 0.2 & 63.0 \\
\hline & & $w^{*}$ & 1.4 & 2.1 & 11.3 & 34.6 & 1.6 & 11.3 & 0.6 & 3.7 & 0.2 & 0.2 & 32.7 \\
\hline & & i & 0.8 & 0.7 & 3.4 & 25.9 & 0.5 & 2.3 & 0.5 & 1.5 & 0.2 & 0.4 & 63.9 \\
\hline & & $r$ & 2.0 & 3.3 & 21.4 & 37.9 & 3.9 & 1.0 & 0.1 & 15.9 & 0.2 & & 14.3 \\
\hline \multirow{12}{*}{ Type II } & \multirow{3}{*}{ PE17 } & 0 & 0.9 & 0.6 & 4.5 & 26.8 & 1.0 & 4.3 & 0.2 & 1.4 & & & 60.4 \\
\hline & & w & 2.0 & 3.0 & 15.4 & 51.4 & 2.6 & 14.4 & 0.7 & 5.4 & & & 4.1 \\
\hline & & $\mathrm{i}$ & 0.7 & 0.6 & 4.0 & 27.0 & 0.7 & 3.3 & 0.1 & 1.3 & & & 61.8 \\
\hline & \multirow{3}{*}{ PE21 } & 0 & 0.7 & 0.9 & 3.6 & 25.7 & 0.6 & 3.2 & 0.2 & 1.7 & & & 62.9 \\
\hline & & w & 2.3 & 3.2 & 16.3 & 45.8 & 2.7 & 15.7 & 0.9 & 6.0 & & 0.9 & 5.8 \\
\hline & & i & 0.7 & 0.9 & 3.7 & 24.6 & 0.8 & 3.9 & 0.2 & 1.3 & & & 63.5 \\
\hline & \multirow{2}{*}{ PE61 } & 0 & 0.4 & 0.5 & 2.7 & 25.5 & 0.6 & 3.3 & 0.3 & 1.3 & & & 65.1 \\
\hline & & w & 1.6 & 2.5 & 16.7 & 47.8 & 2.2 & 16.7 & 0.8 & 6.0 & & & 4.9 \\
\hline & \multirow{4}{*}{ PE97 } & 0 & 0.8 & 0.3 & 2.0 & 23.5 & 0.6 & 0.1 & & 0.5 & & & 71.4 \\
\hline & & w & 1.6 & 2.2 & 17.0 & 47.5 & 2.7 & 16.6 & 0.8 & 6.1 & & & 5.2 \\
\hline & & $\mathrm{i}$ & 0.8 & 0.3 & 2.9 & 27.1 & 0.7 & 0.8 & & 0.7 & & & 66.1 \\
\hline & & d & 0.9 & 0.5 & 3.8 & 30.0 & 0.7 & 1.6 & 0.3 & 1.2 & 0.2 & 0.3 & 60.6 \\
\hline
\end{tabular}


Table IV. Chemical analyses of the slags

\begin{tabular}{lcccccccccccccccc}
\hline & $\mathrm{Na}_{2} \mathrm{O}$ & $\mathrm{MgO}$ & $\mathrm{Al}_{2} \mathrm{O}_{3}$ & $\mathrm{SiO}_{2}$ & $\mathrm{P}_{2} \mathrm{O}_{3}$ & $\mathrm{SO}_{3}$ & $\mathrm{~K}_{2} \mathrm{O}$ & $\mathrm{CaO}$ & $\mathrm{TiO}_{2}$ & $\mathrm{MnO}$ & $\mathrm{FeO}$ & $\mathrm{CuO}$ & $\mathrm{ZnO}_{2}$ & $\mathrm{Sb}_{2} \mathrm{O}_{3}$ & $\mathrm{BaO}$ & $\mathrm{PbO}$ \\
\hline $\mathrm{SL} 381$ & 0.8 & 3.5 & 7.9 & 38.0 & 1.8 & 0.4 & 2.6 & 12.9 & 0.4 & 0.8 & 18.3 & & 0.5 & & 2.6 & 6.7 \\
\hline $\mathrm{SL} 382$ & 0.7 & 5.8 & 5.3 & 35.6 & 1.8 & 0.3 & 1.8 & 17.3 & 0.4 & 0.8 & 10.9 & 0.1 & 0.5 & & 6.9 & 5.9 \\
\hline $\mathrm{SL} 383$ & 0.6 & 5.3 & 6.4 & 39.1 & 1.3 & 0.2 & 1.9 & 16.5 & 0.4 & 0.8 & 13.1 & & 0.8 & & 3.7 & 4.9 \\
\hline $\mathrm{SL} 385$ & 0.7 & 5.1 & 5.1 & 36.2 & 1.6 & 0.4 & 1.8 & 17.4 & 0.3 & 0.9 & 14.5 & & 0.4 & & 2.7 & 7.9 \\
\hline $\mathrm{SL} 340$ & 0.9 & 3.2 & 8.0 & 37.0 & 1.7 & 0.3 & 2.4 & 12.8 & 0.4 & 0.7 & 17.3 & 0.1 & 0.7 & 0.9 & 2.8 & 6.1 \\
\hline
\end{tabular}


Table V. Chemical analyses of the glass chunk.

\begin{tabular}{ccccccccccc}
\hline & $\mathrm{Na}_{2} \mathrm{O}$ & $\mathrm{MgO}$ & $\mathrm{Al}_{2} \mathrm{O}_{3}$ & $\mathrm{SiO}_{2}$ & $\mathrm{~K}_{2} \mathrm{O}$ & $\mathrm{CaO}$ & $\mathrm{FeO}$ & $\mathrm{CuO}$ & $\mathrm{BaO}$ & $\mathrm{PbO}$ \\
\hline $\mathrm{SL30R}$ & 0.5 & 0.1 & 0.9 & 20.9 & 0.3 & 1.2 & 0.5 & 1.5 & 0.2 & 71.2 \\
\hline $\mathrm{SL30N}$ & 0.3 & 0.4 & 1.5 & 20.8 & 0.4 & 1.9 & 0.7 & 2.8 & 0.1 & 69.0 \\
\hline
\end{tabular}

